\title{
39. VARIATIONS OF POROSITY IN CALCAREOUS SEDIMENTS FROM THE ONTONG JAVA PLATEAU ${ }^{\prime}$
}

\author{
Franck C. Bassinot, ${ }^{2}$ Janice C. Marsters,${ }^{3}$ Larry A. Mayer, ${ }^{4}$ and Roy H. Wilkens ${ }^{3}$
}

\begin{abstract}
Based on index properties measurements made on board the JOIDES Resolution, we studied porosity changes with depth in the fairly homogeneous deep-sea calcareous sediments cored during Ocean Drilling Program Leg 130 on the Ontong Java Plateau.

Using Leg 130 data, we present evidence that the rate of porosity decrease with burial in calcareous oozes and chalks is related to the depth of deposition and thus probably depends on the "conditioning" of calcareous sediments by winnowing or dissolution processes during the time of deposition. The ooze-to-chalk transition is not clearly reflected in porosity profiles. In the ooze-chalk sections studied (the upper $600 \mathrm{mbsf}$ ), mechanical compaction is most likely the major process controlling the porosity decrease with depth of burial, whereas the chalk-limestone transition (at about $1100 \mathrm{mbsf}$ at Site 807) is characterized by an intense chemical compaction leading to a drastic decrease in porosity values within $100 \mathrm{~m}$.

In oozes and chalks, porosity values were corrected to "original" (uncompacted) values using site-specific empirical regression equations. When plotted vs. age, corrected porosity profiles appear to correlate quite well from site to site in the sediments deposited during the last 15 m.y. This observation has considerable implications for seismic stratigraphy.

Our attempt to correlate variations in porosity (or wet-bulk density) profiles with changes in carbonate content remained unsatisfactory. Index properties changes are likely caused by changes in the foraminifer content. If this is the case, we propose that large-scale porosity fluctuations that correlate from site to site are the result of changes in the surface productivity that lead to changes in the foraminifers-to-nannofossils ratio.
\end{abstract}

\section{INTRODUCTION}

Based on Deep Sea Drilling Project (DSDP) and Ocean Drilling Program (ODP) data, numerous studies have been conducted on changes of porosity and wet-bulk density with depth of burial and age in pelagic calcareous sediments (Schlanger and Douglas, 1974; Hamilton, 1976; Milholland et al., 1980; Kim et al., 1985; Wilkens and Handyside, 1985). Reduction in porosity with burial (and a concomitant increase in wet-bulk density) is controlled by two main mechanisms: (1) mechanical compaction, the dewatering of sediments and reorientation and repacking of grains; and (2) chemical compaction, the dissolution of calcite at grain contacts and the precipitation of authigenetic calcite in voids and at sites of lesser stress (a good review of burial diagenesis processes can be found in Scholle and Halley, 1985).

These compaction processes are complex. They not only depend on the continuous increase of overburden pressure with burial but are also controlled by many other factors, such as sediment composition or local heat flow value (which both play a major role in chemical compaction (e.g., Schlanger and Douglas, 1974; Wetzel, 1989). Despite this complexity, many efforts have been dedicated to the quantification and modeling of porosity and density changes with burial. Modeling is useful for numerous basic or applied purposes, such as gravity studies of the oceanic crust (Hamilton, 1976), the prediction of elastic wave velocities in seismic interpretation (Hamilton, 1976), or the quantification of pore fluid migration in compacting sedimentary sections (Einsele, 1977; de Caritat, 1989). Furthermore, if burial effects on porosity and density can be quantified, corrections can be applied to retrieve "original" (uncompacted) porosity and density

\footnotetext{
'Berger, W.H., Kroenke, L.W., Mayer, L.A., et al., 1993. Proc. ODP, Sci. Results. 130: College Station, TX (Ocean Drilling Program).

${ }^{2}$ Laboratoire de Géologie du Quaternaire, Case 907, CNRS-Luminy, 13288 Marseille Cedex 9, France.

${ }^{3}$ Department of Geology and Geophysics, School of Ocean and Earth Science and Technology, University of Hawaii, 2525 Correa Road, Honolulu, HI 96822, U.S.A.

${ }^{4}$ Ocean Mapping Group, Department of Surveying Engineering, University of New Brunswick, P.O. Box 4400, Fredericton, New Brunswick E3B 5A3, Canada.
}

values. These original values only depend on changes in sediment composition and therefore provide valuable information on depositional processes and on changes in the sedimentary environment.

Recent works have shown the importance of these corrections in high-resolution studies using continuously recorded physical properties logs. For instance, in piston cores from the eastern equatorial Pacific, Mayer (1979) has shown that wet-bulk density can be used as a proxy for carbonate content. In DSDP/ODP sites from that area, when densities are corrected for burial effects, the continuous and high-resolution record of density obtained with the gamma-ray attenuation porosity evaluator (GRAPE) can be used to provide ultrahigh resolution carbonate curves (Mayer, 1991). High-resolution studies of density and porosity changes recorded with the GRAPE have recently been proposed for deep-sea calcareous sediments of other areas (Herbert and Mayer, 1991). For such studies, it is necessary to quantify accurately porosity and density changes with burial.

Mainly because of their implications in oil recovery, numerous studies have been conducted on predictive equations and the modeling of porosity loss with increasing depth of burial in terrigenous sediments (Athy, 1930; Hedberg, 1936). There is less work on deepsea pelagic sediments. Based on DSDP data, Hamilton (1976) empirically derived polynomial equations of porosity and density vs. depth for various types of deep-sea sediments (pelagic clay, radiolarian ooze, diatomaceous ooze, and calcareous ooze). These generalized equations give an approximate idea of how porosity evolves with depth of burial. However, understanding burial effects in deep-sea sediments, and especially in pelagic calcareous sediments, still requires much work.

During Leg 130, nearly $4800 \mathrm{~m}$ of pelagic calcareous sediments were recovered from 16 holes drilled at 5 sites (803-807) on a depth transect located in the northeastern part of the Ontong Java Plateau (Fig. 1; Kroenke, Berger, Janecek, et al., 1991). The absence of major disturbances in the sediment column at 4 of the 5 sites as well as the compositional homogeneity of these calcareous sediments at each site seemed to be very promising for a study of burial effects on the porosities of pure calcareous pelagic sediments. These data are also very interesting in a study of the relationship between index properties and sediment composition. The high quantity and good quality of 


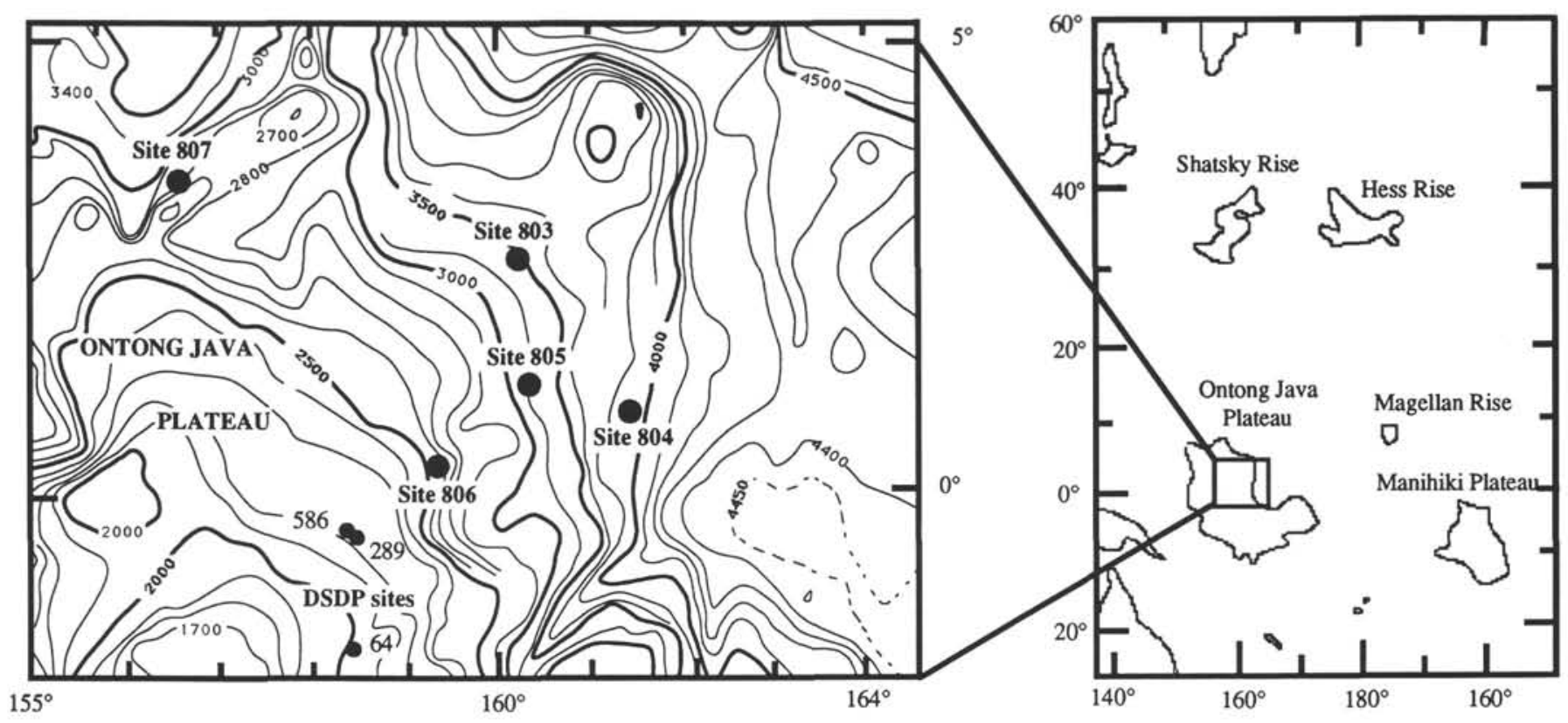

Figure 1. Locations of Leg 130 and previous DSDP drilling sites on the northeastern portion of the Ontong Java Plateau. Bathymetric contours are in meters.

index-properties laboratory measurements at Leg 130 sites were especially suitable for such studies.

\section{SITE SELECTION}

To obtain the simplest signal of burial compaction, we decided to study only sections that were not affected by major postdepositional reworking. Seismic lines recorded when approaching Site 804 clearly show that this site was affected by mass movement. Seismic profiles exhibit irregular seismic reflections and show evidence of wedging. Physical properties profiles at Site 804 reflect these major sediment disturbances. Intervals of anomalously low porosities have been interpreted as reflecting rapid consolidation caused by enhanced dewatering during slumping (Kroenke, Berger, Janecek, et al., 1991). Thus, we did not study Site 804.

The four sites selected for this study provide a nearly continuous record of calcareous pelagic sediments deposited at different water depths on the Ontong Java Plateau: Sites $803(3410 \mathrm{~m}), 805$ (3188 m), $806(2520 \mathrm{~m})$, and $807(2805 \mathrm{~m})$. Of special interest is the study of Sites 803,805 , and 806 . These sites are close geographically and lie beneath pelagic ocean waters that display homogeneous biogenic productivity such that the quantity and composition of sediment supply can be assumed to have always been equivalent. Therefore, differences in physical properties and in compaction behavior at these sites can be ascribed to dissolution and winnowing effects on sediment composition during the time of deposition. We studied porosity changes in the calcareous ooze and chalk interval within the upper $600 \mathrm{mbsf}$ at Sites $803,805,806$, and 807 , and porosity changes in limestone at Site 807.

\section{METHODS}

Fulthorpe et al. (1989) have shown that logging data from the Ontong Java Plateau yield a reliable measure of in-situ sediment physical properties. In this study, however, we chose to use shipboard laboratory porosity and density values instead of borehole log values for two reasons: (1) laboratory profiles cover the entire sedimentary sections, whereas logged profiles start at about $100 \mathrm{mbsf}$; and (2) sedimentological analyses (such as carbonate content) were performed on the same sample taken for index properties measurements.
Thus, cross-correlation studies of index properties and sediment composition are easier with shipboard index properties data.

We were aware that elastic rebound caused by the removal of overburden pressure, which has been observed in other deposits (Hamilton, 1976; Marine Geotechnical Consortium, 1985), may have led to small discrepancies between the shipboard laboratory porosity and density values and the true in-situ values. However, Urmos et al. (this volume), by comparing Leg 130 laboratory and log density and porosity data, show that differences between in-situ and lab values are very small $(1 \%-2 \%)$ and remain relatively constant with burial. Such results imply that pelagic carbonate sediments on the Ontong Java Plateau have undergone mostly plastic deformation during burial and thus show little elastic rebound of their mineral matrix when retrieved from borehole and brought to laboratory conditions. This conclusion is supported by results of laboratory consolidation tests. These tests performed on ooze and chalk samples from Sites 803 and 807 yielded estimates of mechanical porosity rebound of $<0.1 \%$ over a 1000-m equivalent depth range (Lind, this volume). Urmos et al. (this volume) applied a simple hydraulic rebound correction to the laboratory data that compensates for pore fluid expansion during core recovery. This correction is very small and relatively constant, so it does not affect significantly the total amounts of porosity and the porosity-depth trends. Therefore, in this study, we did not find it necessary to correct shipboard measurements to in-situ values. We shall keep in mind, however, that in-situ porosities are slightly lower than shipboard measured values.

Porosities $(\phi)$ and wet-bulk densities (WBD) of discrete samples were calculated on board the JOIDES Resolution from measurements of wet and dry weights and dry volume. Sample weights were determined to a precision of $\pm 0.01 \mathrm{~g}$ using a Scitech electronic balance. Volumes were determined using a Quantachrome Penta-pycnometer (a helium-displacement pycnometer). The Quantachrome pycnometer measured volumes to an approximate precision of $10^{-4} \mathrm{~cm}^{3}$.

At Site 803 (the first site of Leg 130), each sample was run twice through the pycnometer for wet and dry volumes. It quickly became apparent that the samples from subsequent sites should only be run once if we were to keep up with the desired sampling frequency. Furthermore, dry volumes measured by the pycnometer are probably more accurate than wet volumes because the presence of volatiles in the wet samples may result in erroneous pressure readings. Therefore, 
for subsequent Leg 130 sites, only dry samples were run through the pycnometer. Dry weight and volume measurements were obtained after the samples were oven dried at $110^{\circ} \mathrm{C}$ for $24 \mathrm{hr}$ and allowed to cool in a desiccator.

Porosity was calculated from the wet and dry weights $\left(W_{w}\right.$ and $W_{d}$, respectively) and dry volume $\left(V_{d}\right)$. The wet volume $\left(V_{w}\right)$ was calculated by adding the volume of the water lost through drying of the sample to the dry volume, using the following equation:

$$
V_{w}=V_{d}+\left[\left(W_{w}-W_{d}\right) / d_{f}\right]
$$

where $d_{f}$ is the density of evaporated water (assumed equal to $1 \mathrm{~g} / \mathrm{cm}^{3}$ at laboratory conditions). The dry volume, $V_{d}$, includes both the volume of the sediment or rock constituents and the volume of salt remaining in the dry sample. Salt-corrected porosity $(\phi)$ was then calculated according to Hamilton (1971) assuming a 35-ppt interstitial fluid salinity and a seawater density of $1.0245 \mathrm{~g} / \mathrm{cm}^{3}$ at laboratory conditions:

$$
\phi=\left[\left(W_{w}-W_{d}\right) /(1-0.035)\right] /\left[1.0245 \cdot V_{w}\right],
$$

Wet-bulk density (WBD) was calculated using the calculated wet volume $\left(V_{w} ; \mathrm{Eq} .1\right)$ and the wet weight $\left(W_{w}\right)$ according to Boyce's equation (1973):

$$
\mathrm{WBD}=W_{w} / V_{w}
$$

\section{POROSITY CHANGES WITH BURIAL \\ Sediment Composition, Porosity, and Wet-bulk Density Changes}

The sediments retrieved in the upper $600 \mathrm{mbsf}$ at the Leg 130 sites consist of Pleistocene to upper Eocene calcareous oozes and chalks made of nannofossils with varying amounts of foraminifers. At each site, because of the fairly uniform sediment composition, sedimentary sequences were divided into subunits based on the degree of consolidation. At Site 807, Eocene to Cretaceous limestones were cored between 1098 and 1351 mbsf.

In the intervals studied, the mineralogical composition of Ontong Java Plateau sediments is dominated by biogenic calcite with variable, but minor, amounts of biogenic silica (nonbiogenic components always represent $<5 \%$ abundance). If we except small ash layers and some Eocene radiolarian-rich intervals (at Site 807), the carbonate content of the calcareous sediments is usually high, ranging from $80 \%$ to $95 \%$.

In Figure 2, porosity-depth curves of the upper $600 \mathrm{mbsf}$ are presented for Holes 803D, 805B, 806B, and 807A. Profiles show a clear trend of decreasing porosity with depth of burial. Porosity ranges from about $72 \%$ at the tops of sections to values as low as $40 \%$ (around $600 \mathrm{mbsf}$ in Hole 803D).

Ooze-chalk transitions, as assigned by sedimentologists on board Leg 130, are marked by small arrows in Figure 2 (Site 803: $217 \mathrm{mbsf}$; Site 805: 294 mbsf; Site 806: 339 mbsf; and Site 807: 293 mbsf). Whatever the site considered, no evidence exists for a clear change in the porosity-depth trend at about the ooze-chalk transition.

Superimposed on the general trends of decreasing porosities with burial are second-order fluctuations of tens of meters of wavelength (Fig. 2). These fluctuations probably reflect changes in sediment composition. They will be studied in more detail in the following section when porosity profiles are corrected to "original" values.

Density curves are not presented in this paper because porosity and density profiles are mirror images of one another, as shown by the high correlation coefficients of regression equations calculated for the porosity vs. density plots displayed in Figure 3. In marine sediments, wet-bulk density (WBD) depends on porosity $(\phi)$ and on grain density $\left(D_{g}\right)$ :

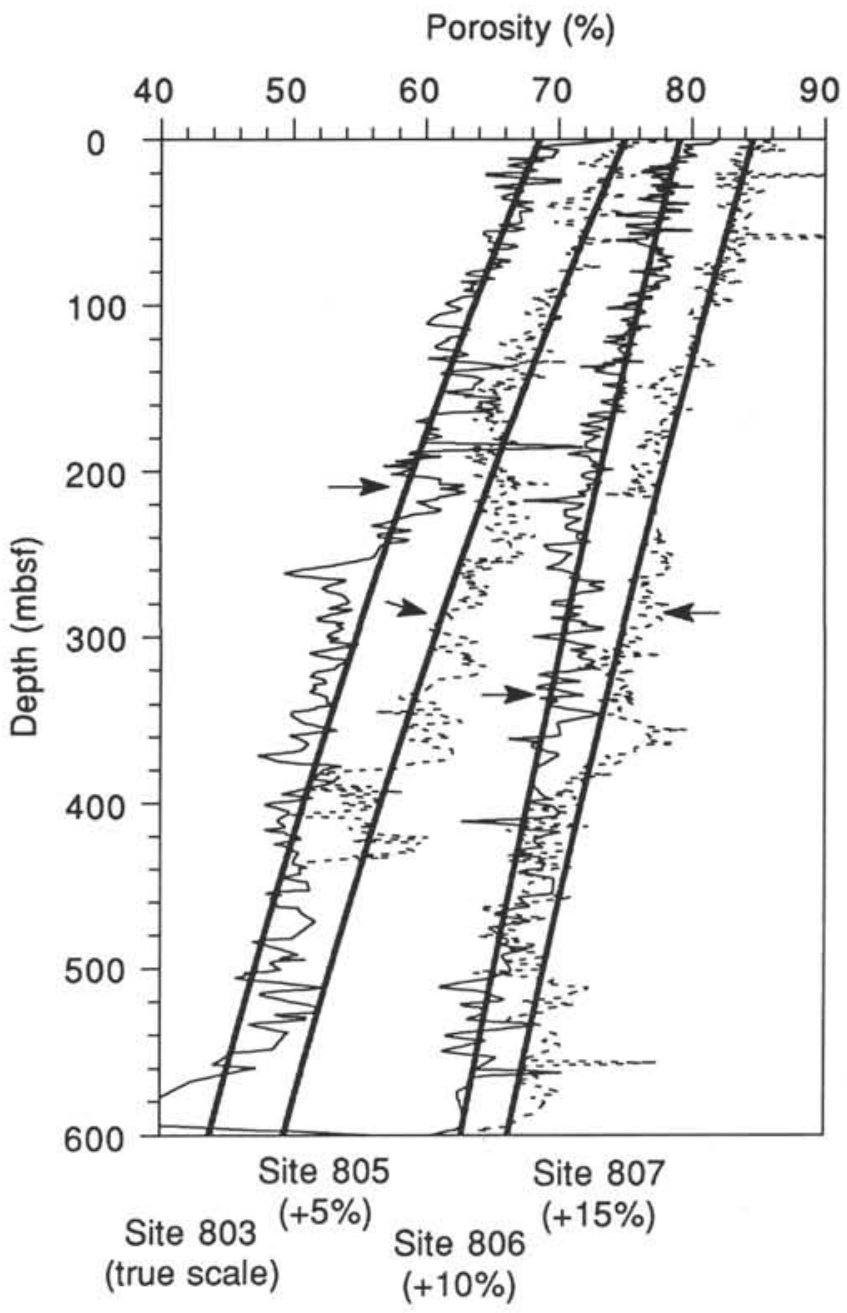

Figure 2. Porosity-depth curves for Holes 803D, 805B, 806B, and 807A plotted with exponential regression curves calculated at each site (regression equations are given in Table 1). Arrows indicate ooze-chalk transitions as identified by sedimentologists on board Leg 130 .

$$
\mathrm{WBD}=\phi \cdot D_{w}+(1-\phi) \cdot D_{g},
$$

where $D_{w}=$ the density of interstitial water.

In Leg 130 sites, because of the fairly homogeneous mineralogical composition of the sediments (dominated by biogenic calcite), grain density at all sites averages $2.68 \mathrm{~g} / \mathrm{cm}^{3}$ (calcite has a grain density of $2.7 \mathrm{~g} / \mathrm{cm}^{3}$ ) and shows minor-amplitude changes (see "Physical Properties" chapters in Kroenke, Berger, Janecek, et al., 1991). Interpolating the wet-bulk density at the zero porosity point for Site 807 (Fig. 3) shows that for this site, where high carbonate contents were measured (up to $99 \%$ ), the mean grain density is $2.719 \mathrm{~g} / \mathrm{cm}^{3}$, the grain density of pure calcite. In Equation 4, porosity is the only variable that displays large-amplitude changes, thus explaining the good densityporosity relationship.

As seen above, sediment drilled at all Leg 130 sites are fairly uniform in composition (calcareous sediments made of nannofossils with varying amounts of foraminifers). At each site, considering the absence of major changes in the sedimentary column, we assumed that the general trend of decreasing porosity with depth of burial only results from compaction processes (mechanical or chemical). Given this assumption, compaction effects in ooze and chalk intervals were empirically quantified by applying standard regression techniques on porosity-depth data from the upper $600 \mathrm{mbsf}$ at Sites 803, 805, 806, and 807 (porosity-depth profiles at each site were obtained by merg- 

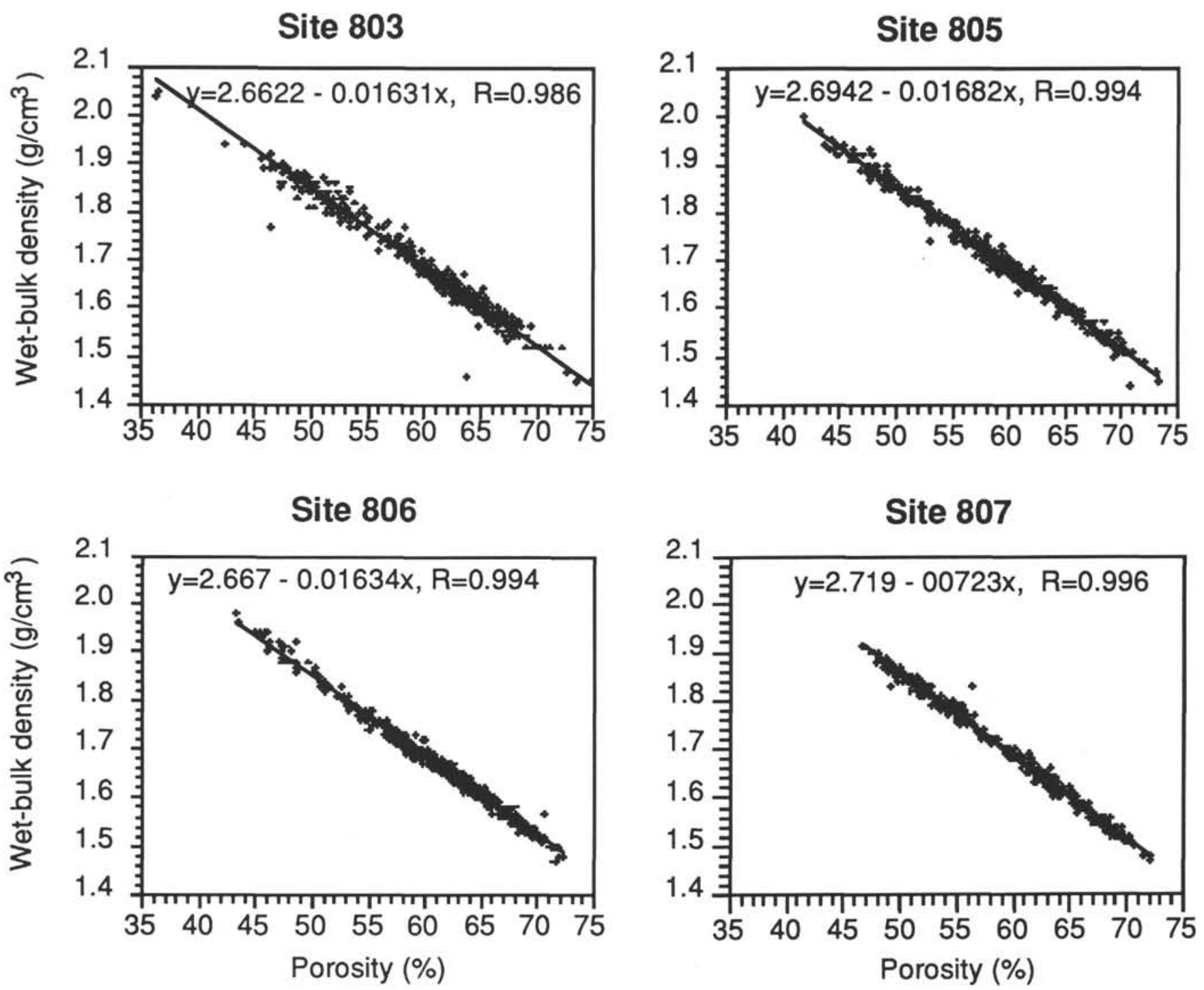

Figure 3. Regression of wet-bulk density vs. porosity for Sites $803,805,806$, and 807 .

ing data sets from the different holes). Calculations showed that smooth exponential equations satisfactorily fit the porosity-depth curves. The regression curves are superimposed on the measured porosity-depth profiles in Figure 2, and the regression equations are presented in Table 1. Site 803, however, displays a little divergence from the regression curve below $250 \mathrm{mbsf}$. From the top of the section to $250 \mathrm{mbsf}$, the exponential equation fits the porosity-depth curve well. At about $250 \mathrm{mbsf}$, a small drop in porosity values marks the beginning of an interval that shows only minor decreases in porosity with depth of burial and thus diverges from the regression curve. The reason for this remains unexplained at present although it is worth noting that the top of this interval corresponds to a hiatus spanning almost $5 \mathrm{~m}$.y. between 15 and $20 \mathrm{Ma}$.

Regression equations at all sites yield nearly identical porosity values (around 69\%) at the sediment surface (Fig. 2 and Table 1). This means that porosities in uncompacted sediments fluctuate around mean values that are fairly identical whatever the depth of deposition. Hamilton et al. (1982) had shown that porosity values of surficial sediments show only little change in a depth transect on the flank of the Ontong Java Plateau. In Ontong Java Plateau sediments, a significant amount of foraminifers is present. Because these foraminifer tests are hollow, they result in higher porosity sediment than similarsized solid particles and cause intraparticle porosity (i.e., voids within tests) as well as interparticle porosity (Hamilton et al., 1982; Bachman, 1984). Hamilton et al, suggested that "the small change in total porosity with water depth for the Plateau samples is a result of the intraparticle porosity being gradually transferred to interparticle porosity as the test walls on the sand-sized Foraminifera break down under dissolution which increases with water depth" (Hamilton et al., 1982, pp. 742-743).

\section{Porosity Changes with Depth of Burial: Mechanical vs. Chemical Compaction}

Based on DSDP data, Schlanger and Douglas (1974) proposed a diagenetic model for calcareous sediments. In this model, two stages are present in the reduction of porosity with depth of burial: (1) an early dewatering stage in the upper $200 \mathrm{mbsf}$, in which porosity is reduced from about $80 \%$ to $60 \%$ and the dominant mechanism is mechanical compaction; and (2) a slower dewatering stage in which porosity is reduced from about $65 \%$ to $40 \%$ between 200 and 1000 mbsf and the dominant mechanism is cementation. Recent studies have shown that the initiation of cementation through solution-precipitation mechanisms may occur more rapidly (after burial of a few tens of meters) in the calcareous sedimentary column, with cement reaching about $25 \%$ of the solid volume at the ooze-chalk 
Table 1. Equations of the regression curves that fit porosity-depth profiles at Sites $\mathbf{8 0 3}, \mathbf{8 0 5}, \mathbf{8 0 6}$, and $\mathbf{8 0 7}$, and mean grain sizes measured in oozes cored at these same sites.

\begin{tabular}{|c|c|c|c|}
\hline Sites & $\begin{array}{c}\text { Water depths } \\
(\mathrm{mbs})\end{array}$ & $\begin{array}{c}\text { Regression equations } \\
\text { and } \\
\text { compaction parameters }\end{array}$ & $\begin{array}{c}\text { Mean grain sizes } \\
(\mu \mathrm{m})\end{array}$ \\
\hline 803 & 3410 & $\begin{array}{c}\theta=68.6 \exp (-0.00075 . z) \\
B=0.00075\end{array}$ & 20 \\
805 & 3188 & $\begin{array}{c}\sigma=70.2 \exp (-0.00076 . z) \\
B=0.00076\end{array}$ & 18 \\
806 & 2520 & $\begin{array}{c}\sigma=69.2 \exp (-0.00045 . z) \\
B=0.00045\end{array}$ & 25 \\
807 & 2805 & $\begin{array}{c}\sigma=69.6 \exp (-0.00051 . z) \\
B=0.00051\end{array}$ & 29 \\
\hline
\end{tabular}

transition (Wetzel, 1989). However, in Leg 130 sites, this is not the case. Based on consolidation test results and on SEM observations, Lind (this volume) concludes that apparently chemical compaction is of minor importance in ooze and chalk samples from Sites 803 and 807. Furthermore, no marked change exists in the trends of the porosity-depth curves within the ooze-chalk intervals studied (Fig. 2). The fact that "smooth" exponential curves can satisfactorily fit the porosity-depth profiles might indicate that the processes that reduce pore space in oozes and chalks act continuously from the sediment surface to about $600 \mathrm{mbsf}$. Given these observations, we conclude that mechanical compaction is most likely the major process acting throughout the entire ooze-chalk sections studied.

Site 807 provides a good opportunity to study the compaction effects on porosity at deeper depths in limestone. At this site, sediments cored consist of Pleistocene to Cretaceous ooze to limestone calcareous sediments. Radiolarian-rich intervals and chert layers of Eocene age were encountered. Samples with carbonate content lower than $90 \%$ were removed from our data base. Thus, by looking at porosity changes in fairly homogeneous sediments (in terms of carbonate content), we focused only on compaction processes and avoided effects caused by important changes in sediment composition.

The compaction model calculated for the upper $600 \mathrm{~m}$ of the ooze-chalk interval of Site 807 was interpolated into the limestone interval and was superimposed on the measured porosity-depth profile (Fig. 4). Clear divergences from the compaction model are seen in the deep part of Site 807.

The rate of porosity loss is maximum between 1050 and $1150 \mathrm{mbsf}$, with porosity being reduced from $48 \%$ to about $15 \%$ within $100 \mathrm{~m}$. This rapid decrease corresponds to the onset of limestone formation that first appears at about $1000 \mathrm{mbsf}$ and is dominant below $1100 \mathrm{mbsf}$ (chalk-limestone transition at 1100 mbsf, in Kroenke, Berger, Janecek, et al., 1991). Smear slides indicate that between 1060 and 1140 mbsf a transition occurs from material dominated by calcareous nannofossils to material dominated by unidentified carbonate particles. Below $1140 \mathrm{mbsf}$, these unidentified carbonate particles constitute up to $90 \%$ of the limestone. We assume that these unidentified carbonate particles are authigenetic calcite precipitated during chemical compaction processes. Thus, below 1140 mbsf, most of the initial biogenic carbonate has been reprecipitated into authigenetic calcite. Below about $700 \mathrm{mbsf}$, occurrences of small microstylolites have been noted by sedimentologists (Kroenke, Berger, Janecek, et al., 1991). With increasing depth of burial, these microstylolites grade into flaser structures and well-developed stylolites. These stylolites are especially well developed in the limestone interval. All these observations clearly show that the drastic porosity reduction at the chalk-limestone transition is caused by major chemical compaction processes.

Stylolite-like features indicate that calcite has been removed almost totally from some intervals. This calcite is available for the infilling of the void space of adjacent layers. Thus, porosity reduction not only results from changes in the shape and distribution of solids in a given volume of sediment but also (mainly?) from the introduction of "external" solids (calcite) that come from nearby stylolite-like layers. Why such a drastic chemical compaction occurs so rapidly at about the chalk-limestone transition still remains under question.

\section{Differences in Compaction Behavior among Leg 130 Sites}

The regression curves displayed in Figure 5 clearly show that, despite the almost identical porosity values at the sediment surface, rates of porosity loss with burial vary from site to site depending on the water depth. Rates at the deeper sites (Sites 803 at 3410 m, and Site 805 at $3188 \mathrm{~m}$ ) are higher than those at the shallower sites (Sites 806 at $2520 \mathrm{~m}$, and Site 807 at $2805 \mathrm{~m}$; Fig. 5). Sites 803, 805, and 806 are close geographically so that the quantity and composition of the sediment supply have always been equivalent. Thus, differences in compaction behavior can be confidently ascribed to "conditioning" of the sediments during the time of deposition by either dissolution processes or current winnowing at the seafloor. The compaction behavior of Ontong Java Plateau sediments changes rapidly between water depths of 2800 and $3200 \mathrm{~m}$, which correspond to those at Sites 805 and 807 respectively.

In surficial sediments from Ontong Java Plateau, studies have shown that dissolution and winnowing lead to the reduction of mean grain size with depth of deposition (Johnson et al., 1977; Hamilton et al., 1982). At each site, we averaged the grain-size data obtained on board the JOIDES Resolution (Table 1; Kroenke, Berger, Janecek, et al., 1991). This rough grain-size information shows that sediments from the deeper sites (Sites 803 and 805) are statistically finer than sediments from the shallower sites (Sites 806 and 807). Fine calcareous sediments usually lose their porosity more rapidly during burial than coarse sediments (Scholle and Halley, 1985), and thus differences in grain size might explain why porosity is reduced more rapidly in the deeper sites of Leg 130 . However, differences in compaction behavior between fine and coarse sediments are usually ascribed to the fact that coarse sediments reach a resistant grain-supported framework when compacted. In the shallower Leg 130 sites, we do not think that sediment can reach a grain-supported framework during compaction. Thus, we suggest that another mechanism more than likely explains the differences between compaction behaviors of Leg 130 sediments.

At the Ontong Java Plateau, dissolution processes lead to the higher fragmentation of weakened foraminifers deposited at deeper sites (Johnson et al., 1977; Hamilton et al., 1982). The breakdown of foraminifers results in the intraparticle porosity within foraminifer chambers being transferred to interparticle porosity (Hamilton et al., 1982). Intraparticle porosity is only slightly affected by compaction. Geotechnical studies have shown that when foraminifers are surrounded by a fine-grained matrix they hardly break down during compaction (Valent et al., 1982); thus, voids in foraminifer chambers are preserved and intraparticle porosity does not significantly change. Consolidation tests performed on ooze and chalk samples from Leg 130 also clearly show that interparticle porosity is the most effective porosity as far as mechanical compaction is concerned (Lind, this volume). Thus, we suggest that sediments from the deep sites are more rapidly and strongly affected by compaction than sediments from the shallow sites because they have a higher ratio of interparticle vs. intraparticle porosity.

\section{INTERSITE COMPARISON OF POROSITY VS. AGE PROFILES}

\section{Correction of Porosities: Calculation of Uncompacted Values}

The correction of porosities to retrieve uncompacted values is necessary for two main purposes: (1) correlation of original porosity changes with such sedimentological parameters as carbonate content 


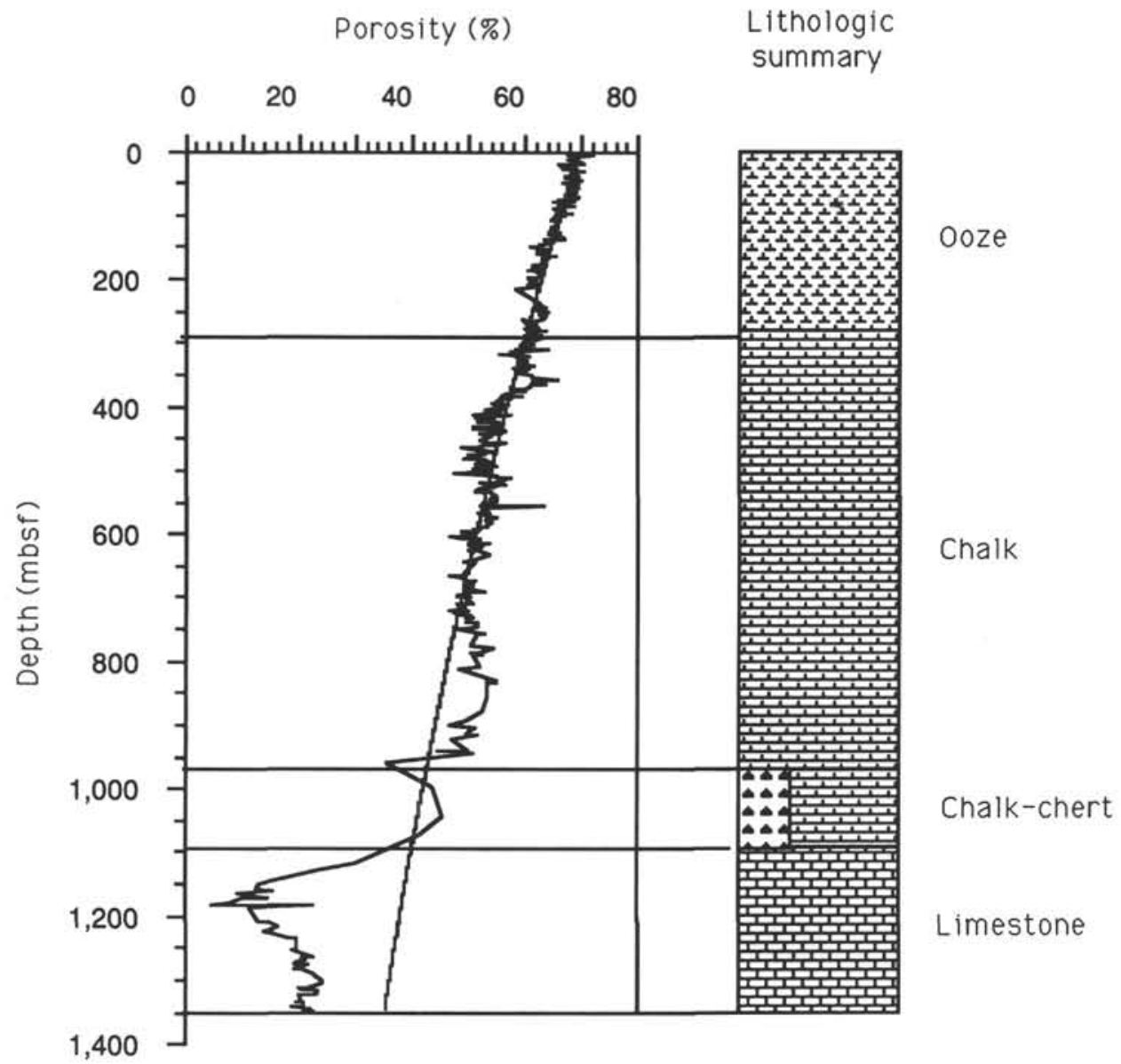

Figure 4. Regression curve calculated in the first $600 \mathrm{mbsf}$ of Site 807 is interpolated at deeper depths and superimposed on the total porosity-depth curve of Site 807 (merged data sets from Holes 807A and 807C). A clear divergence between the model and the porosity-depth curve is seen at about the chalk-limestone transition. Major chemical compaction processes explain the rapid decrease in porosity.

or grain size, and (2) comparison of original porosities from sediment of different sites to analyze the effects of site location (water depth, etc.) on index properties of surficial sediments.

In the ooze and chalk intervals, we used the empirically derived porosity regression equations to correct measured porosities to original (uncompacted) values. The exponential regression equations that fit the data are similar to the porosity-depth relationships formulated by Athy (1930) for mechanical compaction in fine terrigenous sediments. In Athy's equation, sediment deposits are characterized by a compression parameter $\beta$. This compression parameter is dependent on sediment composition, but it is independent of depth of burial. When the original porosity $\left(\phi_{0}\right)$ is known, porosity $(\phi)$ at a depth of burial $z$ is given by:

$$
\phi=\phi_{0} \cdot \exp (-\beta z)
$$

By analogy to Athy's formula, constants that appear in the exponential term of our regression equations (Table 1) can be considered as empirically defined compaction parameters. The compaction behavior of sediments cored within the first hundred meters of the sites studied is totally defined by these compaction parameters $\beta$. As seen above, these parameters are dependent on the depth of deposition. At each site, initial (uncompacted) porosities $\left(\phi_{\mathrm{o}}\right)$ were calculated using measured porosities $(\phi)$ and the compaction parameters by

$$
\phi_{\mathrm{o}}=\phi / \exp (-\beta z)
$$

where $z$ is the depth in meters below seafloor. The result of such a correction is displayed in Figure 6, which illustrates the uncorrected and corrected porosity profiles at Site 807 .

\section{Intersite Comparison of Corrected Porosity vs. Age Profiles}

We used the age-depth model derived from the biostratigraphy and the few available magnetostratigraphy data to construct corrected porosity vs. age profiles at Holes 803D, 805B, 806B, and 807A. Depth-age control points are those selected in the "Sedimentation Rates" chapters of the Initial Reports (Kroenke, Berger, Janecek, et al., 1991; Table 2). Based on this time scale, we converted the data from the depth domain into the time domain by linear interpolation between age control points. A few dubious porosity values were removed from the data sets before corrected data were plotted as a function of age for intersite comparisons. At Hole 803D, we also removed the high porosity values recorded in the ash layer encountered at 180 mbsf (Kroenke, Berger, Janecek, et al., 1991). Before plotting, data were smoothed by a 3-point running average.

It is beyond the scope of this study to look at possible correlations of small-scale porosity fluctuations among the Leg 130 sites. The comparison of laboratory porosity profiles recorded in two different holes drilled at a same site (Fig. 7) clearly shows that minor scale fluctuations are not well resolved by laboratory profiles. Improve- 


\section{Porosity (\%)}

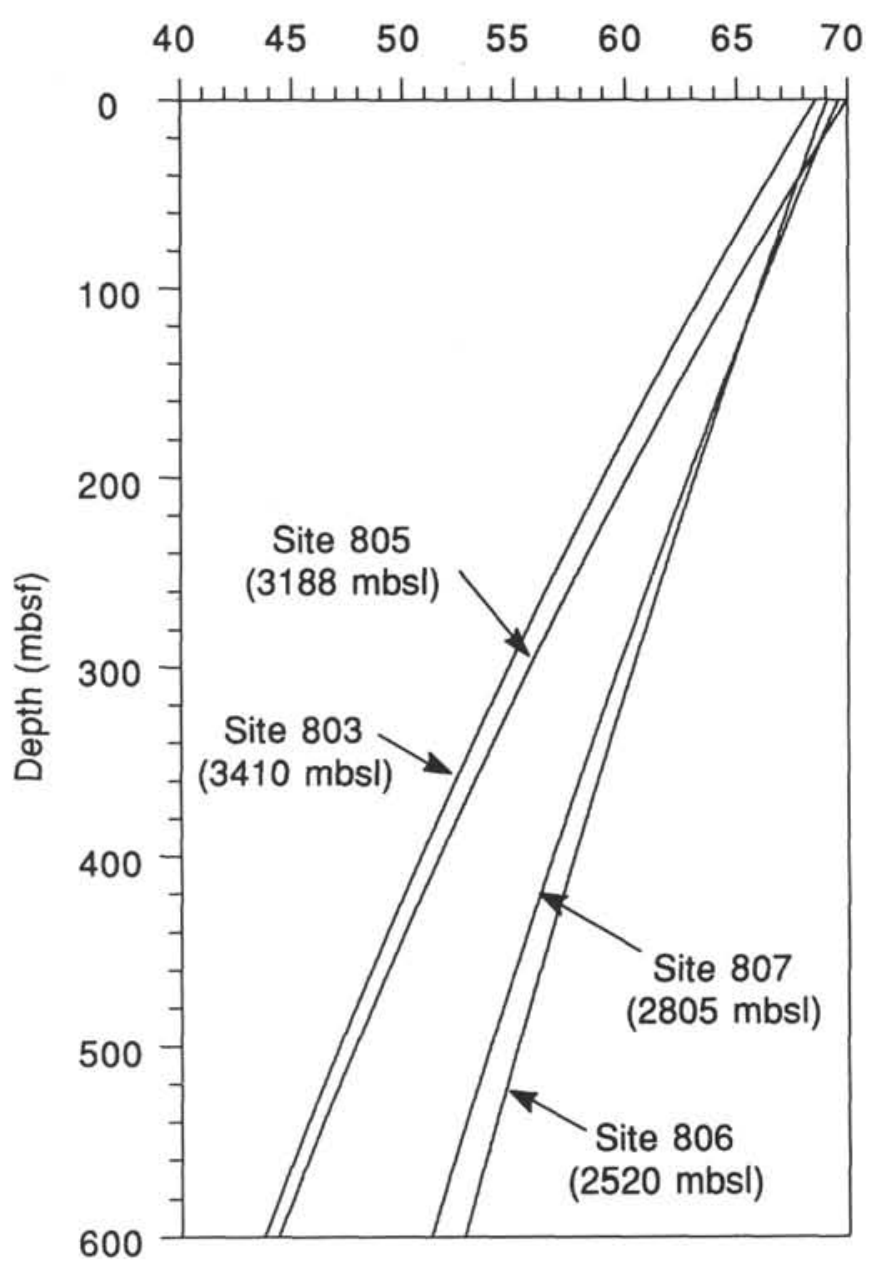

Figure 5. Regression curves for Sites 803, 805, 806, and 807 (regression equations are given in Table 1). The rate of porosity decrease with depth of burial is related to water depths of sites.

ments in the depth-age models and the use of continuously recorded GRAPE data will make it possible to look at these small-scale changes in more detail in an upcoming paper.

Corrected porosity values are plotted as a function of age and are compared among sites in Figure 8. For the last 15 m.y., large-scale fluctuations in the porosity profiles appear to correlate quite well from site to site. Profiles are not well correlated for older times. Thus, in the upper part of the sedimentary sections cored during Leg 130, large-scale porosity fluctuations may be controlled by regional paleoceanographic changes. Such a result has considerable implications for the seismic stratigraphy. As seen previously, wet-bulk density changes are primarily a function of porosity changes. Previous studies have shown that, in the upper section of deep-sea calcareous sediments, wet-bulk density changes dominate acoustic impedance contrasts (Mayer et al., 1985). Thus, a correlation of porosity profiles among sites implies that, at levels at which abrupt changes in porosity occur, we would expect to find time-equivalent reflectors. A shift that is well correlated among the sites occurs, for instance, at about 7 Ma (Fig. 8).

Johnson et al. (1977) and Hamilton et al. (1982) have shown that porosities from surficial sediments are only weakly affected by dissolution with increasing water depth. Enhanced dissolution with depth of deposition leads to the transfer of intraparticle to interparticle

\section{Porosity (\%)}

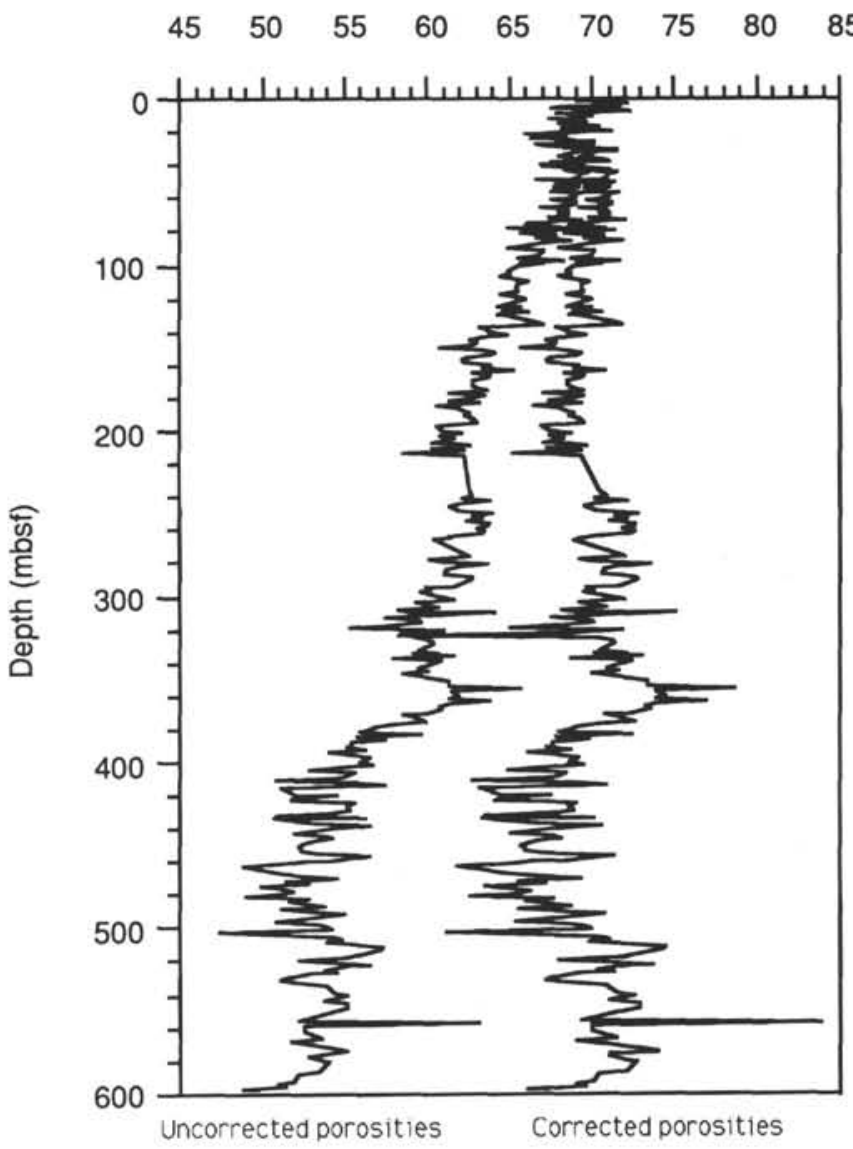

Figure 6. Comparison of uncorrected porosity curve at Hole 807A with the corrected (uncompacted) porosity curve.

porosity as foraminifers break down, with no major loss in total porosity. Our results show that this could have been true during the last 15 m.y. Indeed, not only major porosity fluctuations correlate between sites, but also little difference seems to be present between the absolute values of porosity in time-equivalent layers (Fig. 8).

In their study of density and carbonate data from Atlantic and equatorial Pacific DSDP/ODP sites, Herbert and Mayer (1991) have concluded that density in calcareous sediments is dominated by differences in packing rather than by differences in mineral grain densities. Such a conclusion is applicable to the carbonate-rich sediments of the Ontong Java Plateau as density changes are controlled by changes in porosity in these sediments (Fig. 3). Porosity (which reflects the amount of voids in a given volume of sediment and is, therefore, tightly related to packing) displays large-scale fluctuations, whereas grain density shows only minor changes (see "Physical Properties" chapters in Kroenke, Berger, Janecek, et al., 1991) because of the fairly homogeneous mineralogical composition of the sediments.

In pelagic carbonate sediments from the east and central equatorial Pacific, index properties are sensitive to sediment composition and are especially well correlated to changes in carbonate content (Mayer, 1979; Luz and Shackleton, 1975). Packing is controlled by the amount of porous tests of radiolarians that compose the noncarbonate fraction. The carbonate-free material has an average porosity of $90 \%$, whereas pure carbonate has a porosity of $55 \%$ (Wilkens and Handyside, 1985). In Ontong Java Plateau sediments, however, changes in index properties are not related to changes in carbonate content. When corrected porosities are plotted vs. carbonate con- 
Table 2. Bio- and magnetostratigraphic events used as control points for depth-age conversion at Holes 803D, 805B, 806B, and 807A.

\begin{tabular}{lccccc}
\hline \multicolumn{1}{c}{ Event } & $\begin{array}{r}\text { Age } \\
\text { (Ma) }\end{array}$ & $\begin{array}{c}\text { Depth in } \\
\text { Hole 803D } \\
\text { (mbsf) }\end{array}$ & $\begin{array}{c}\text { Depth in } \\
\text { Hole 805B } \\
\text { (mbsf) }\end{array}$ & $\begin{array}{c}\text { Depth in } \\
\text { Hole 806B } \\
\text { (mbsf) }\end{array}$ & $\begin{array}{c}\text { Depth in } \\
\text { Hole 807A } \\
\text { (mbsf) }\end{array}$ \\
\hline Olduvai (O) & 1.88 & 17.60 & 31.60 & - & - \\
LO D. brouweri & 1.89 & - & - & 40.25 & - \\
OA D. triradiatus & 2.07 & - & - & - & 31.15 \\
Gauss (T) & 2.47 & 26.40 & - & - & - \\
Mammoth (O) & 3.18 & 36.50 & - & - & - \\
LO R. pseudoumbilica & 3.56 & 43.30 & 77.95 & 95.00 & 78.65 \\
LO D. quinqueramus & 5.00 & 69.85 & 125.45 & - & 126.15 \\
LO D. hamatus & 8.70 & 174.35 & 268.05 & 334.55 & 288.10 \\
LO S. heteromorphus & 13.60 & 221.95 & 325.25 & 477.95 & 374.60 \\
FO G. peripheroacuta & 14.90 & 239.15 & 354.20 & 516.45 & 403.75 \\
LO S. belemnos & 18.80 & - & 392.85 & - & - \\
LO T. carinatus & 19.50 & 246.60 & - & - & - \\
FO S. belemnos & 20.00 & 255.50 & - & 603.45 & - \\
LO G. kugleri & 21.80 & 260.30 & 440.75 & 651.35 & 509.95 \\
FO G. kugleri & 23.70 & 317.85 & - & - & - \\
LO G. opima & 28.20 & 346.80 & - & - & 702.35 \\
\hline
\end{tabular}

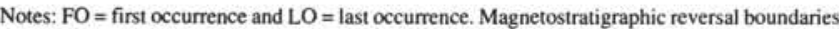
followed by designation $(\mathrm{T})$ or $(\mathrm{O})$ refer to "termination" or "onset," respectively.

tents, coefficients of linear regressions are always lower than 0.2. At Leg 130 sites, only a little variability is present in the carbonate content. However, minor changes in carbonate content may correspond to important modifications in grain-size distribution and grain shape (Johnson et al., 1977; Hamilton et al., 1982), both of these parameters being important factors for sediment fabric and packing that control index properties changes. Therefore, it is not surprising that important porosity changes exist in sediments that display few carbonate content fluctuations.

In their high-resolution study of the upper $165 \mathrm{~m}$ at Site 806 , Mayer et al. (this volume) show that density fluctuations at the Milankovitch periods result from changes in grain size. As grain size increases, density decreases (and porosity increases). These authors attribute the changes in grain size to the removal of fine particles by winnowing, leaving a greater percentage of large hollow foraminifers behind. Indeed, Wu and Berger (1991) have shown that sedimentation on the top of the Ontong Java Plateau (above a water depth of about $2500 \mathrm{~m}$ ) was significantly affected by bottom currents during Pleistocene ice ages with enhanced winnowing during glacial periods. The large-scale porosity fluctuations that correlate from site to site in Figure 8 may also be controlled by changes in the foraminifer content. If this is the case, however, winnowing cannot be invoked here as a driving mechanism. Fine particles removed by bottom currents on the top of the plateau are redeposited downslope, thus contributing significantly to the net decrease of grain size with increasing water depth (Johnson et al., 1977).

Wu and Berger (1991) pointed out that because of the transport of fines downslope, winnowing seems restricted to shallower depths even though it may also proceeds at greater depths. The shallower sites lose fine particles, whereas the deeper sites gain fine particles; therefore, winnowing has a different effect on sedimentation at the top and the flank of the plateau in terms of grain size and foraminifer vs. nannofossil ratio. Thus, if large-scale porosity fluctuations that correlate among the Leg 130 sites (ranging from water depths of 2500 to $3410 \mathrm{~m}$ ) are indeed controlled by changes in foraminifer content, we suggest that these changes are controlled by changes in surface productivity through changes in the foraminifer to nannofossil ratio.

\section{CONCLUSION}

Sites cored during Leg 130 on the Ontong Java Plateau made it possible to study compaction effects on porosity profiles recorded in fairly homogeneous deep-sea calcareous sediments with a high carbonate content. Furthermore, temporal fluctuations related to changes

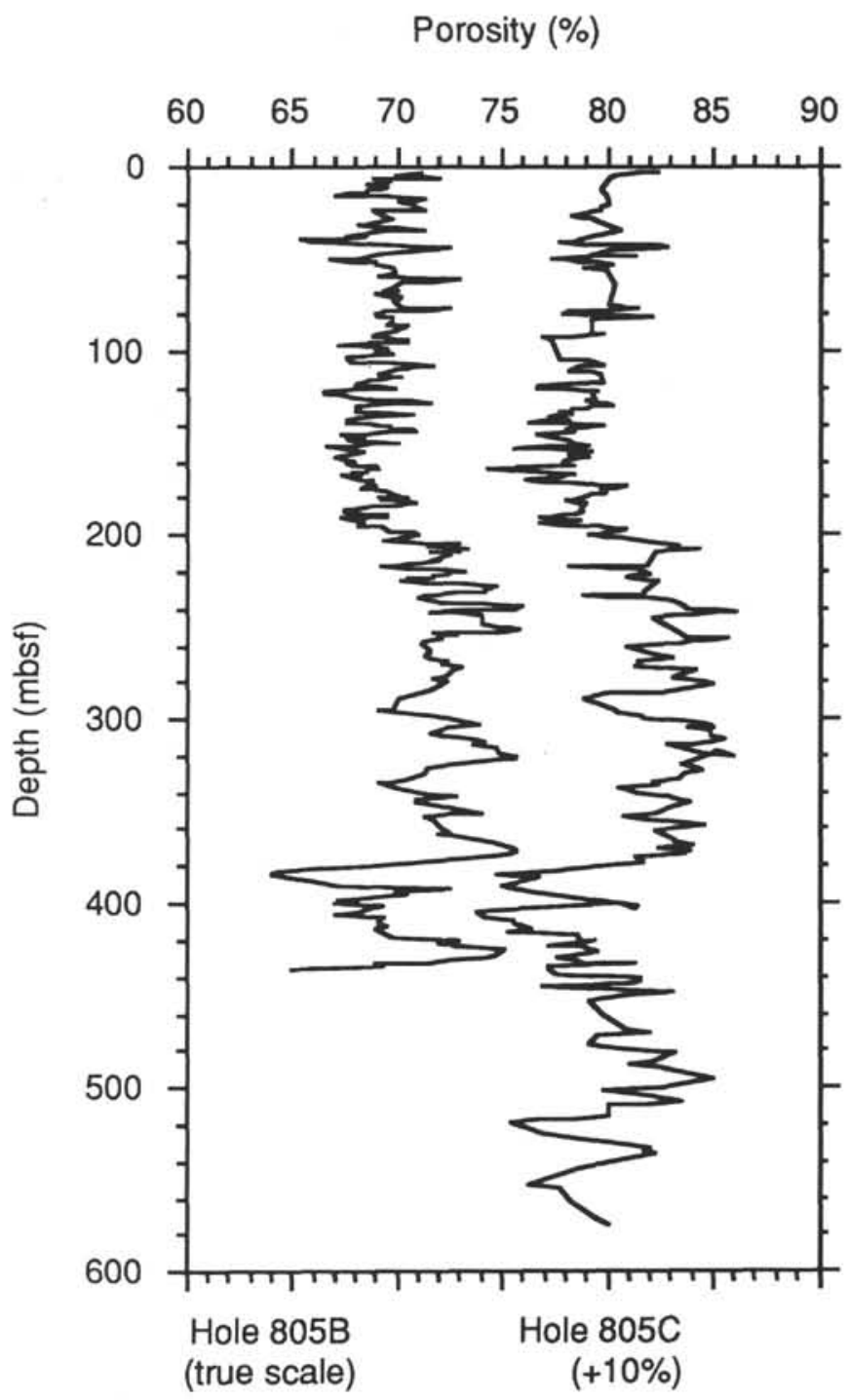

Figure 7. Comparison of porosity-depth profiles from Holes $805 \mathrm{~B}$ and $805 \mathrm{C}$. Large-scale fluctuations are well correlated but not the minor scale changes.

in sediment composition can be studied when porosities are corrected to initial values.

The rate of porosity decrease with depth of burial in oozes and chalks is related to the depth of deposition and thus probably depends on the "conditioning" of calcareous sediments by winnowing or dissolution processes at depth during the time of deposition.

Within the ooze-chalk interval, mechanical compaction is the major process controlling the porosity reduction with depth of burial whereas the chalk-limestone transition is characterized by an intense chemical compaction leading to a drastic decrease in porosity values.

In oozes and chalks, porosities can be corrected to "original" (uncompacted) values using empirically derived equations. When plotted vs. age, large-scale fluctuations in porosity profiles appear to correlate well from site to site during the last $15 \mathrm{~m} . \mathrm{y}$. This observation has considerable implications for seismic stratigraphy. In the upper part of deep-sea calcareous sections, porosity (wet-bulk density) values control the seismic reflection profiles (Mayer et al., 1985). Thus, a good correlation of porosity profiles among the sites implies that, at levels at which abrupt changes in porosity occur, we would expect to find time-equivalent reflectors.

Our attempt to correlate variations in porosity (or wet-bulk density) profiles with changes in carbonate content remained unsat- 
Porosity (\%)

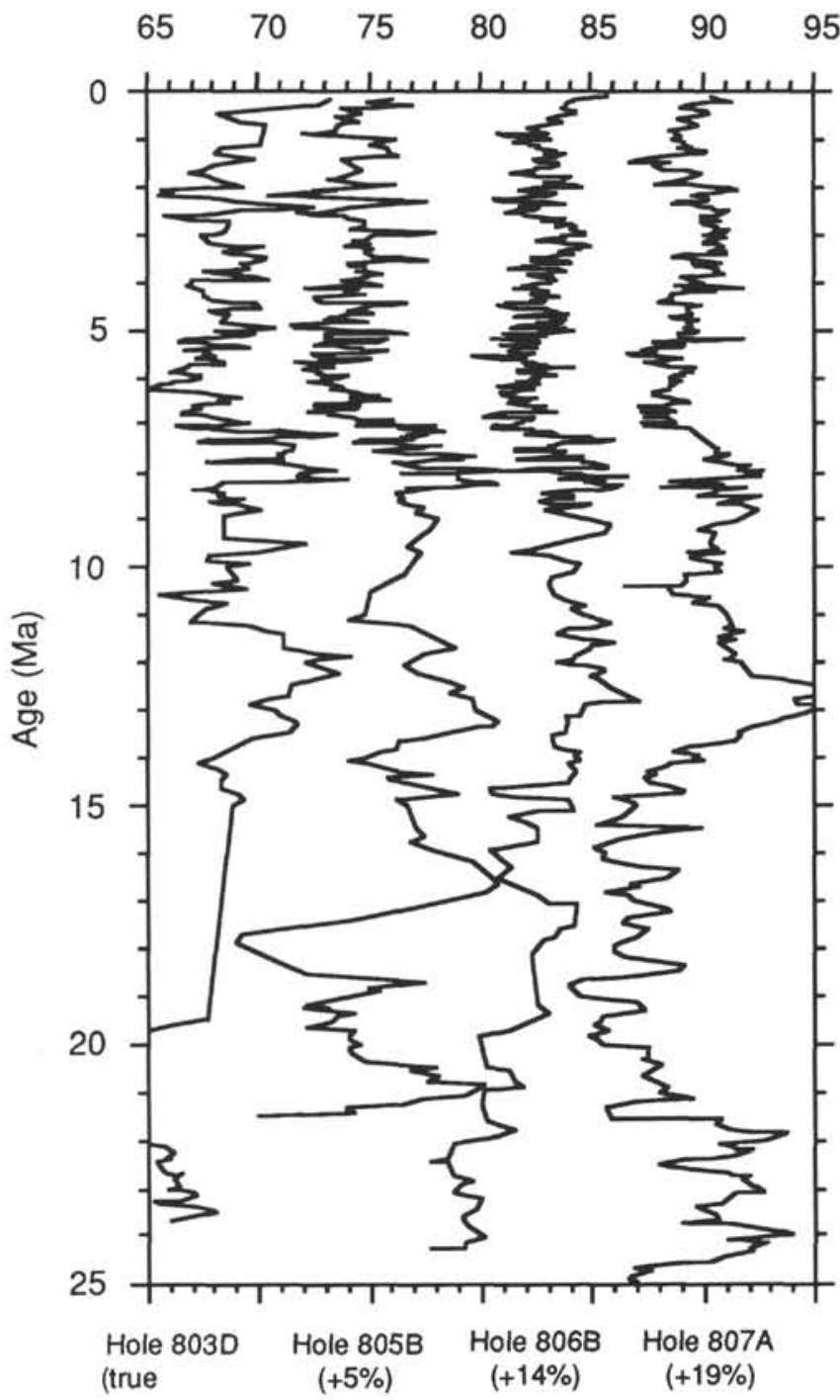

Figure 8. Corrected porosity vs. age at Holes 803D, 805B, 806B, and 807A for the last $25 \mathrm{~m}$.y. Large-scale fluctuations in the porosity profiles appear to be well correlated during the last $15 \mathrm{~m} . \mathrm{y}$. and less so before.

isfactory. Index properties changes are likely a result of changes in the foraminifer content. If this is the case, we propose that large-scale porosity fluctuations that correlate from site to site are caused by changes in the surface productivity that lead to changes in the foraminifer to nannofossil ratio.

\section{ACKNOWLEDGMENTS}

We thank the two reviewers, K.A. Dadey and P. Holler, whose constructive criticisms helped improve the manuscript. F.B. expresses special thanks to F. Rostek for fruitful discussions.

F.B. acknowledges funding from INSU/CNRS under DBT (contribution No. 449) and IST programs.

\section{REFERENCES}

Athy, L.F., 1930. Density, porosity, and compaction of sedimentary rocks. AAPG Bull., 14:1-24.
Bachman, R.T., 1984. Intratest porosity in foraminifera. J. Sediment. Petrol., $54: 257-262$.

Boyce, R.E., 1973. Appendix I. Physical properties-methods. In Edgar, N.T., Saunders, J.B., et al., Init. Repts. DSDP, 15: Washington (U.S. Govt. Printing Office), $1115-1128$.

de Caritat, P., 1989. Note on the maximum upward migration of pore water in response to sediment compaction. Sediment. Geol., 65:371-377.

Einsele, G., 1977. Range, velocity, and material flux of compaction flow in growing sedimentary sequences. Sedimentology, 24:639-655.

Fulthorpe, C.S., Schlanger, S.O., and Jarrard, R.D., 1989. In situ acoustic properties of pelagic sediments on the Ontong Java Plateau. J. Geophys. Res., 94:4025-4032.

Hamilton, E.L., 1971. Prediction of in-situ acoustic and elastic properties of marine sediments. Geophysics, 36:266-284.

1976. Variations of density and porosity with depth in deep-sea sediments. J. Sediment. Petrol., 46:280-300.

Hamilton, E.L., Bachman, R.T., Berger, W.H., Johnson, T.C., and Mayer, L.A., 1982. Acoustic and related properties of calcareous deep-sea sediments. $J$. Sediment. Petrol., 52:733-753.

Hedberg, H.D., 1936. Gravitational compaction of clays and shales. Am. J. Sci., 31:241-287.

Herbert, T.D., and Mayer, L.A., 1991. Long climatic time series from sediment physical property measurements. J. Sediment. Petrol., 61:1089-1108.

Johnson, T.C., Hamilton, E.L., and Berger, W.H., 1977. Physical properties of calcareous ooze: control by dissolution at depth. Mar. Geol., 24:259-277.

Kim, D.C., Manghnani, M.H., and Schlanger, S.O., 1985. The role of diagenesis in the development of physical properties of deep-sea carbonate sediments. Mar, Geol., 69:69-91.

Kroenke, L.W., Berger, W.H., Janecek, T.R., et al., 1991. Proc. ODP, Init. Repts., 130: College Station, TX (Ocean Drilling Program).

Luz, B., and Shackleton, N.J., 1975. $\mathrm{CaCO}_{3}$ solution in the tropical east Pacific during the past 130,000 years. In Sliter, W.V., Bé, A.W.H., and Berger, W.H. (Eds.), Dissolution of Deep-sea Carbonates. Spec. Publ., Cushman Foundation Foram. Res., 13:164-168.

Marine Geotechnical Consortium, 1985. Geotechnical properties of northwest Pacific pelagic clays: Deep Sea Drilling Project Leg 86, Site 576A. In Heath, R.C., Burckle, L.H., et al., Init. Repts. DSDP, 86: Washington (U.S. Govt. Printing Office), 723-758.

Mayer, L. A., 1979. Deep-sea carbonates: acoustic, physical and stratigraphic properties. J. Sediment. Petrol., 49:819-836.

1991. Extraction of high-resolution carbonate data for palaeoclimate reconstruction. Nature, 352:148-150.

Mayer, L.A., Shipley, T.H., Theyer, F., Wilkens, R.W., and Winterer, E.L., 1985. Seismic modeling and paleoceanography at Deep Sea Drilling Project Site 574. In Mayer, L.A., Theyer, F., Thomas, E., et al., Init. Repts. DSDP, 85: Washington (U.S. Govt. Printing Office), 947-970.

Milholland, P.D., Manghnani, M.H., Schlanger, S.O., and Sutton, G., 1980. Geoacoustic modeling of deep-sea carbonate sediments. J. Acoust. Soc. Am., 68:1351-1360.

Schlanger, S.O., and Douglas, R.G., 1974. The pelagic ooze-chalk-limestone transition and its implications for marine stratigraphy. In Hsü, K.J., and Jenkyns, H.C. (Eds.), Pelagic Sediments: On Land and Under the Sea. Spec. Publ., Int. Assoc. Sedimentol., 1:117-148.

Scholle, P.A., and Halley, R.B., 1985. Burial diagenesis: out of sight, out of mind. In Schneidermann, N., and Harris, P.M. (Eds.), Carbonate Cements. Spec. Publ., SEPM, 36:309-334.

Valent, P.J., Altschaeffl, A.G., and Lee, H.J., 1982. Geotechnical properties of two calcareous oozes. In Demars, K.R., and Chaney, R.C. (Eds.), Geotechnical Properties, Behavior, and Performance of Calcareous Soils: Philadelphia, PA (Am. Soc. Testing Materials), 79-96.

Wetzel, A., 1989. Influence of heat flow on ooze/chalk cementation: quantification from consolidation parameters in DSDP Sites 504 and 505 sediments. J. Sediment. Petrol., 59:539-547.

Wilkens, R.H., and Handyside, T., 1985. Physical properties of equatorial Pacific sediments. In Mayer, L.A., Theyer, F., Thomas, E., et al., Init. Repts. DSDP, 85: Washington (U.S. Govt. Printing Office), 839-847.

Wu, G., and Berger, W.H., 1991. Pleistocene $\delta^{18} \mathrm{O}$ records from Ontong Java Plateau: effects of winnowing and dissolution. Mar. Geol., 96:193-209.

Date of initial receipt: 6 December 1991

Date of acceptance: 20 May 1992

Ms 130B-058 